Bull. Chem. Soc. Ethiop. 2019, 33(2), 341-348.

ISSN 1011-3924

(c) 2019 Chemical Society of Ethiopia and The Authors

Printed in Ethiopia

DOI: https://dx.doi.org/10.4314/bcse.v33i2.14

\title{
SYNTHESIS, CHARACTERIZATION AND CRYSTAL STRUCTURES OF TWO NEW PHENOLIC MANNICH BASES
}

\author{
Ayowole O. Ayeni ${ }^{1,2 *}$, Gareth M. Watkins ${ }^{1}$ and Eric C. Hosten ${ }^{3}$ \\ ${ }^{1}$ Department of Chemistry, Rhodes University, Grahamstown, South Africa \\ ${ }^{2}$ Department of Chemistry, Obafemi Awolowo University, Ile Ife, Nigeria \\ ${ }^{3}$ Department of Chemistry, Nelson Mandela University, Port Elizabeth, South Africa
}

(Received December 3, 2018; Revised March 18, 2019; Accepted March 23, 2019)

\begin{abstract}
Two new Mannich bases, 5-methyl-2-((4-(pyridin-2-yl)piperazin-1-yl)methyl)phenol (1) and 5methyl-2-((4-(4-nitrophenyl)piperazin-1-yl)methyl)phenol (2), were prepared and characterized structurally with elemental analysis, IR, UV and NMR spectroscopic techniques as well as single crystal X-ray diffraction. Compound I crystallizes in the monoclinic space group P21/c with unit cell dimensions $a=6.6726(2) \AA, b=$ $17.0542(6) \quad \AA, \mathrm{c}=13.3222(4) \AA, \beta=100.832(1)^{\circ}, \mathrm{V}=1489.00(8) \AA^{3}, \mathrm{Z}=4, \mathrm{R}_{1}=0.0408, \mathrm{wR}_{2}=0.1143$. Compound II crystallizes in the monoclinic space P21 with unit cell dimensions $\mathrm{a}=5.9519(2) \AA \mathrm{A}, \mathrm{b}=17.3315(8)$ $\AA, c=15.7237(7) \AA, \beta=90.348(2)^{\circ}, V=1621.95(12) \AA^{3}, Z=4, R_{1}=0.0353, w_{2}=0.0965$. Both compounds have their structures stabilized by hydrogen bonding and $\pi \cdots \pi$ interactions.
\end{abstract}

KEY WORDS: Mannich base, Piperazine, X-ray diffraction, Hydrogen bonds

\section{INTRODUCTION}

Mannich bases from phenols and acetophenones especially have shown significant corrosion inhibition, anticancer, antimalarial properties in addition to coordination potentials with metal ions of biological interests including biocatalysis $[1,2]$. Our recent research focus has been on the catecholase activities of $\mathrm{Cu}$ (II) and $\mathrm{Fe}$ (III) complexes of specially designed Mannich bases and they have shown promising results in this regard [3-4]. A report on the synthesis and characterisation of two new phenolic Mannich bases with potentially beneficial properties in the field of coordination chemistry; 5-methyl-2-((4-(pyridin-2-yl)piperazin-1-yl)methyl)phenol (I) and 5-methyl-2-((4-(4-nitrophenyl)piperazin-1-yl)methyl)phenol (II), is presented herein.

\section{EXPERIMENTAL}

\section{Materials and measurements}

Formaldehyde, 1-(2-pyridyl)piperazine, 1-(4-nitrophenyl)piperazine and $m$-cresol as well as solvents were purchased from Sigma-Aldrich and used as received. Micro analytical determinations $(\mathrm{C}, \mathrm{H}$ and $\mathrm{N}$ ) were obtained using Elementar Analysensysteme VarioMICRO V1.62 GmbH analysis System. NMR spectra $\left({ }^{1} \mathrm{H}\right.$ and $\left.{ }^{13} \mathrm{C} \mathrm{NMR}\right)$ were acquired in $\mathrm{CDCl}_{3}$ using Bruker AMX $300 \mathrm{MHz}$ spectrometer. Attenuated total reflection Fourier transform infrared (ATR-FTIR) spectra for all the samples were recorded on a PerkinElmer Spectrum 400 spectrophotometer in the range 4000 to $650 \mathrm{~cm}^{-1}$. Electronic spectra were recorded for the solutions of the synthesized compounds in DMF on a Perkin Elmer UV-Vis spectrophotometer model Lamba 25. The melting points were determined on a Gallenkamp melting point apparatus.

*Corresponding author. aayeni@oauife.edu.ng

This work is licensed under the Creative Commons Attribution 4.0 International License 
Synthesis of 5-methyl-2-((4-(pyridin-2-yl)piperazin-1-yl)methyl)phenol (I)

A mixture of $m$-cresol (6 mmol, $0.649 \mathrm{~g}), 1$-(2-pyridyl)piperazine (6 mmol, $0.979 \mathrm{~g})$ and (40 mmol, $3 \mathrm{~mL}$ ) of formaldehyde solution (37\%) were refluxed in $15 \mathrm{~mL}$ of ethanol for $24 \mathrm{~h}$. White crystalline solids were obtained from the reaction mixture upon standing for about 3 days. These were collected, washed with ethanol and dried. Yield was $68 \%$. Single crystals suitable for X-ray diffraction measurements were obtained by recrystallization of the product from chloroform: ethyl acetate mixture. Anal. calcd. (\%) for $\mathrm{C}_{17} \mathrm{H}_{20} \mathrm{~N}_{3} \mathrm{O}: \mathrm{C}, 73.59 ; \mathrm{H}, 8.03 ; \mathrm{N}, 8.58$; found (\%): C, $73.55 ; \mathrm{H}, 8.44 ; \mathrm{N}, 8.70 \%$. M.p. $270{ }^{\circ} \mathrm{C}$. UV $(\lambda): 288$ and $305 \mathrm{~nm}$. IR data (FT-IR, $\mathrm{cm}^{-1}$ ): 3412 (br), 2827 (s), 1592 (s), 1480 (s), 1436 (s), 1382 (w), 1252 (s), 1120 (s), 939 (w), 859 (w), 780 (s), 732 (s), 717 (w). ${ }^{1} \mathrm{H}$ NMR (300 MHz; $\mathrm{CDCl}_{3}$ ): $\delta 10.73$ (s, 1H, OH), 6.68- 8.08 $(\mathrm{m}, 7 \mathrm{H}, \mathrm{Ar} H), 3.72\left(\mathrm{~s}, 2 \mathrm{H}, \mathrm{Ar}-\mathrm{CH}_{2}\right), 3.60\left(\mathrm{t}, 4 \mathrm{H},\left(\mathrm{CH}_{2}\right)_{2} \mathrm{~N}-\right), 2.68\left(\mathrm{t}, 4 \mathrm{H},(\mathrm{CH})_{2} \mathrm{~N}-\right), 2.30(\mathrm{~s}, 3 \mathrm{H}$, $\mathrm{CH}_{3}$-Ar). ${ }^{13} \mathrm{C}$ NMR $\left(75 \mathrm{MHz}, \mathrm{CDCl}_{3}\right): \delta 158.93,157.33,147.69,138.76,137.33,128.28$, $119.73,117.66,116.49,113.45,106.85,61.00,52.02,44.83,20.95$.

Synthesis of 5-methyl-2-((4-(4-nitrophenyl)piperazin-1-yl)methyl)phenol (II)

A mixture of $m$-cresol ( $6 \mathrm{mmol}, 0.649 \mathrm{~g}), 1-(4-$-nitrophenyl)piperazine $(6 \mathrm{mmol}, 1.243 \mathrm{~g})$ and (40 mmol, $3 \mathrm{~mL}$ ) formaldehyde solution $(37 \%)$ in $15 \mathrm{~mL}$ of ethanol were refluxed for $24 \mathrm{~h}$. Solid precipitates were obtained upon leaving the reaction mixture for about a week. This was collected and washed with ethanol. Yield was $70 \%$. Single crystals suitable for X-ray diffraction were obtained by recrystallization of the product from chloroform: ethyl acetate mixture. Anal. calcd (\%). for $\mathrm{C}_{18} \mathrm{H}_{21} \mathrm{~N}_{3} \mathrm{O}_{3}: \mathrm{C}, 66.04 ; \mathrm{H}, 6.47 ; \mathrm{N}, 12.84$; found $(\%)$ : C, 65.57; H, 6.98; N, 12.81\%. M.p. $217^{\circ} \mathrm{C}$. UV ( $(\lambda): 277,369$ and $430 \mathrm{~nm}$. IR data (FT-IR, $\mathrm{cm}^{-1}$ ): 3392 (b), $2828(\mathrm{~s})$, 1591 (s), 1494 (s), 1445 (w), 1325 (s), 1247 (s), 1118 (w), 1002 (s), 825 (s), 755 (s), 695 (w), 668 (w). ${ }^{1} \mathrm{H}$ NMR (300 MHz; $\left.\mathrm{CDCl}_{3}\right): \delta 10.27(\mathrm{~s}, 1 \mathrm{H}, \mathrm{OH}), 6.63-6.91(\mathrm{~m}, 7 \mathrm{H}, \mathrm{Ar} H), 3.75(\mathrm{~s}$, $\left.2 \mathrm{H}, \mathrm{Ar}-\mathrm{CH}_{2}\right), 3.47$ (t, 4H, $\left.\left(\mathrm{CH}_{2}\right)_{2} \mathrm{~N}-\right), 2.72\left(\mathrm{t}, 4 \mathrm{H},\left(\mathrm{CH}_{2}\right)_{2} \mathrm{~N}-\right), 2.30$ (s, 3H, $\left.\mathrm{CH}_{3}-\mathrm{Ar}\right) .{ }^{13} \mathrm{C} \mathrm{NMR}$ $\left(75 \mathrm{MHz} ; \mathrm{CDCl}_{3}\right): \delta 157.19,154.56,139.44,138.96,128.74,125.94,116.94,113.09,61.08$, $51.95,47.09,21.25$.

\section{Data collection, structural determination and refinement}

The data were collected using a Bruker KAPPA APEX II single crystal X-ray diffractometer, with a 4-circle Kappa goniometer and sensitive CCD detector. The instrument used a Molybdenum fine focus sealed X-ray tube as an X-ray source and an Oxford Cryostream 700 system for sample temperature control. Bruker's APEX2 software [5] was used for instrument control. The structure was solved using SHELXT-2014 [6] and refined by least square procedures using SHELXL-2016 [7] with SHELXLE [8] as a graphical interface. Data were recorded for absorption effects using the numerical method implemented in SADABS [5]. The crystallographic data for the compounds are summarized in Table 1. Information on Hydrogen bonding is provided in Table 2 .

\section{RESULTS AND DISCUSSION}

\section{Chemistry}

Compounds I and II were readily synthesized through the reaction of 1:1 molar ratio of $m$-cresol with 1-(2-pyridyl)piperazine and 1-(4-nitrophenyl)piperazine respectively by refluxing in ethanol, in moderately high yields (about $70 \%$ ) and high purity (Scheme 1). Both compounds are soluble in chloroform, DMF and DMSO. Single crystals suitable for X-ray diffraction were obtained by two-solvent recrystallization technique followed by slow evaporation in air. Various 
spectroscopic techniques in addition to single crystal X-ray crystallography were employed to characterise the compounds.

Table 1. Crystallographic and experimental data for the compounds.

\begin{tabular}{|c|c|c|}
\hline Compound & I & II \\
\hline Formula & $\mathrm{C}_{17} \mathrm{H}_{21} \mathrm{~N}_{3} \mathrm{O}$ & $\mathrm{C}_{18} \mathrm{H}_{21} \mathrm{~N}_{3} \mathrm{O}_{3}$ \\
\hline $\mathrm{Mr}$ & 283.37 & 327.38 \\
\hline $\mathrm{T}(\mathrm{K})$ & 200 & 200 \\
\hline Crystal shape/color & Block/white & Block/orange \\
\hline Crystal size $\left(\mathrm{mm}^{3}\right)$ & $0.31 \times 0.39 \times 0.56$ & $0.29 \times 0.58 \times 0.61$ \\
\hline Crystal system & Monoclinic & Monoclinic \\
\hline Space group & $\mathrm{P} 21 / \mathrm{c}$ & P21 \\
\hline $\mathrm{a}(\AA)$ & $6.6726(2)$ & $5.9519(2)$ \\
\hline $\mathrm{b}(\AA)$ & $17.0542(6)$ & $17.3315(8)$ \\
\hline c $(\AA)$ & $13.3222(4)$ & $15.7237(7)$ \\
\hline$\alpha\left(^{\circ}\right)$ & 90 & 90 \\
\hline$\beta\left(^{\circ}\right)$ & $100.832(1)$ & $90.348(2)$ \\
\hline$\gamma\left({ }^{\circ}\right)$ & 90 & 90 \\
\hline $\mathrm{V}\left(\AA^{3}\right)$ & $1489.00(8)$ & $1621.95(12)$ \\
\hline Dc $\left(\mathrm{g} \mathrm{cm}^{-3}\right)$ & 1.264 & 1.341 \\
\hline$\mu(\mathrm{Mo}-\mathrm{K} \alpha$ & 0.081 & 0.093 \\
\hline $\mathrm{F}(000)$ & 608 & 696 \\
\hline Reflections collected & 20944 & 23493 \\
\hline Unique reflections & 3707 & 7948 \\
\hline Observed reflections $(I \geq 2 \sigma$ & 2815 & 7011 \\
\hline Parameters & 192 & 437 \\
\hline $\mathrm{R}_{1}, \mathrm{wR}_{2}$ & $0.0408,0.1143$ & $0.0353,0.0965$ \\
\hline$\theta \max / \mathrm{deg}$ & $2.0 / 28.3$ & $1.3 / 28.3$ \\
\hline Rint & 0.018 & 0.017 \\
\hline $\min / \max$ & $-0.16 / 0.21$ & $-0.19 / 0.20$ \\
\hline
\end{tabular}

Table 2. Hydrogen bond distances $(\AA)$ and bond angles $\left(^{\circ}\right)$ for the compounds.

\begin{tabular}{|l|l|l|l|l|}
\hline $\mathrm{D}-\mathrm{H} \cdots \mathrm{A}$ & $\mathrm{d}(\mathrm{D}-\mathrm{H})$ & $\mathrm{d}(\mathrm{H} \cdots \mathrm{A})$ & $\mathrm{d}(\mathrm{D} \cdots \mathrm{A})$ & Angle(D-H $\cdots \mathrm{A})$ \\
\hline $\mathbf{I}$ & & & & \\
\hline $\mathrm{O} 1-\mathrm{H} 1 \cdots \mathrm{N} 1$ & 0.8400 & 1.98 & $2.72(13$ & 146.00 \\
\hline $\mathrm{C} 1-\mathrm{H} 1 \mathrm{E} \cdots \mathrm{O} 1$ & 0.98 & 2.55 & $3.4345(17)$ & 151.00 \\
\hline $\mathrm{C} 22-\mathrm{H} 22 \mathrm{~A} \cdots \mathrm{N} 3$ & 0.99 & 2.38 & $2.7702(16)$ & 103.00 \\
\hline II & & & & \\
\hline $\mathrm{O} 11-\mathrm{H} 11 \cdots \mathrm{N} 11$ & 0.84 & 2.00 & $2.736(2)$ & 145.00 \\
\hline $\mathrm{O} 21-\mathrm{H} 21 \cdots \mathrm{N} 21$ & 0.84 & 1.97 & $2.703(2)$ & 146.00 \\
\hline $\mathrm{C} 121-\mathrm{H} 12 \mathrm{D} \cdots \mathrm{O} 13$ & 0.99 & 2.41 & $3.024(3)$ & 120.00 \\
\hline $\mathrm{C} 21-\mathrm{H} 21 \mathrm{~A} \cdots \mathrm{O} 23$ & 0.98 & 2.56 & $3.524(3)$ & 169.00 \\
\hline $\mathrm{C} 224-\mathrm{H} 22 \mathrm{~J} \cdots \mathrm{O} 23$ & 0.99 & 2.40 & $3.095(3)$ & 127.00 \\
\hline $\mathrm{C} 235-\mathrm{H} 235 \cdots \mathrm{O} 11$ & 0.95 & 2.58 & $3.478(2)$ & 158.00 \\
\hline
\end{tabular}




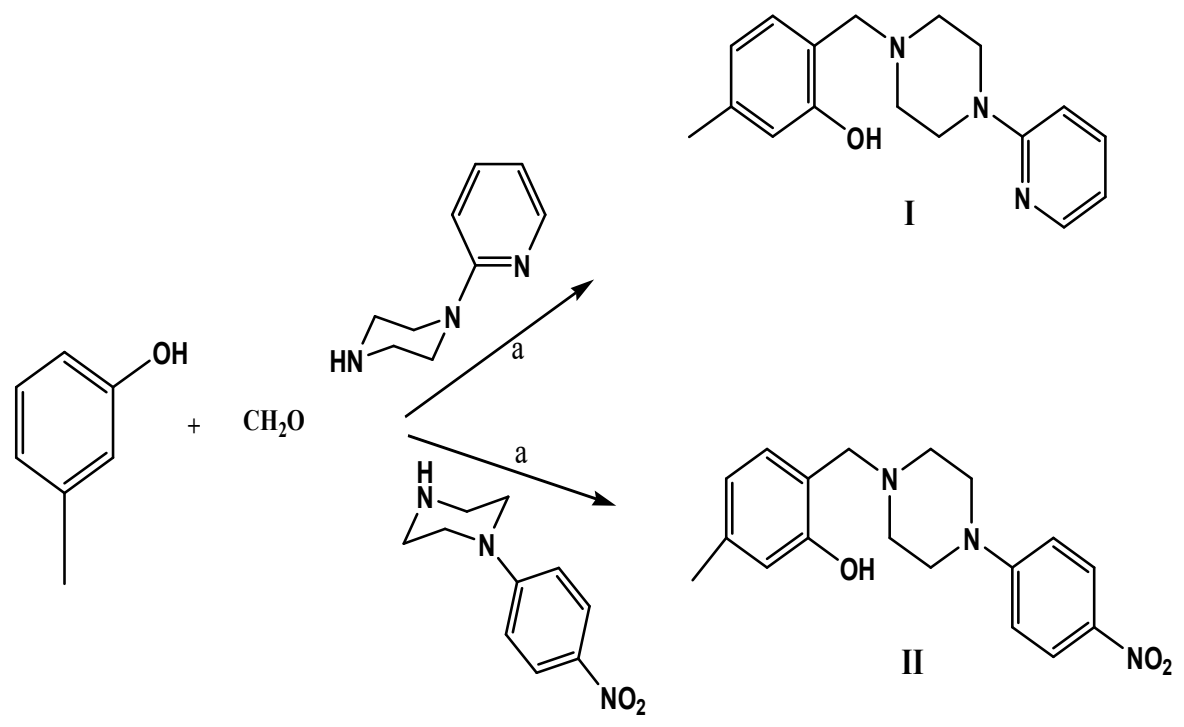

Scheme 1. Reagents and conditions (a) EtOH, $80{ }^{\circ} \mathrm{C}, 24 \mathrm{~h}$.

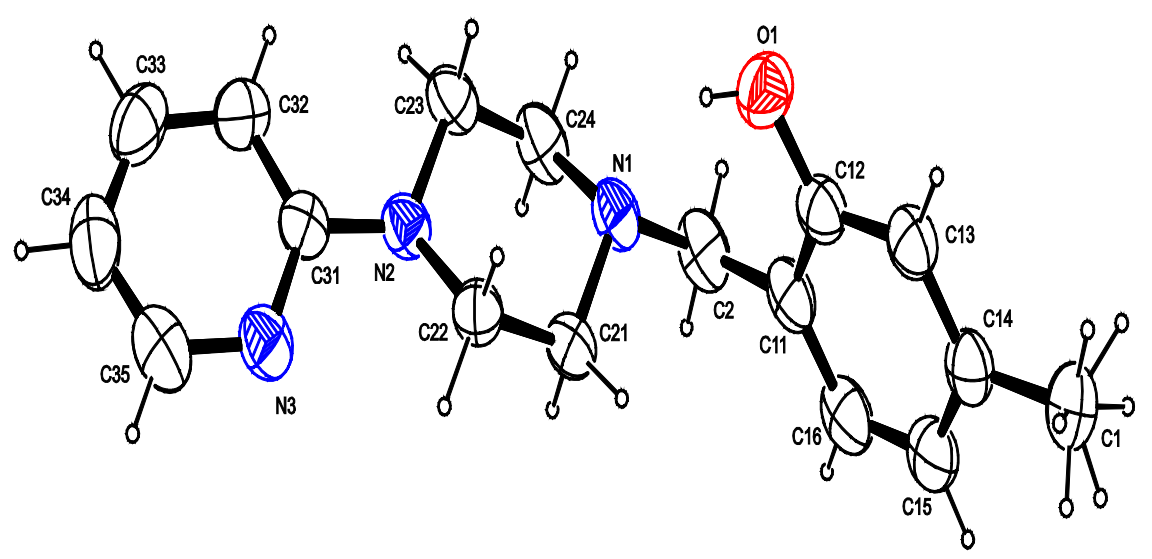

Figure 1. A perspective view of the molecular structure of $\mathbf{I}$ with the atom labelling scheme. Thermal ellipsoids are drawn at the $50 \%$ probability level. 


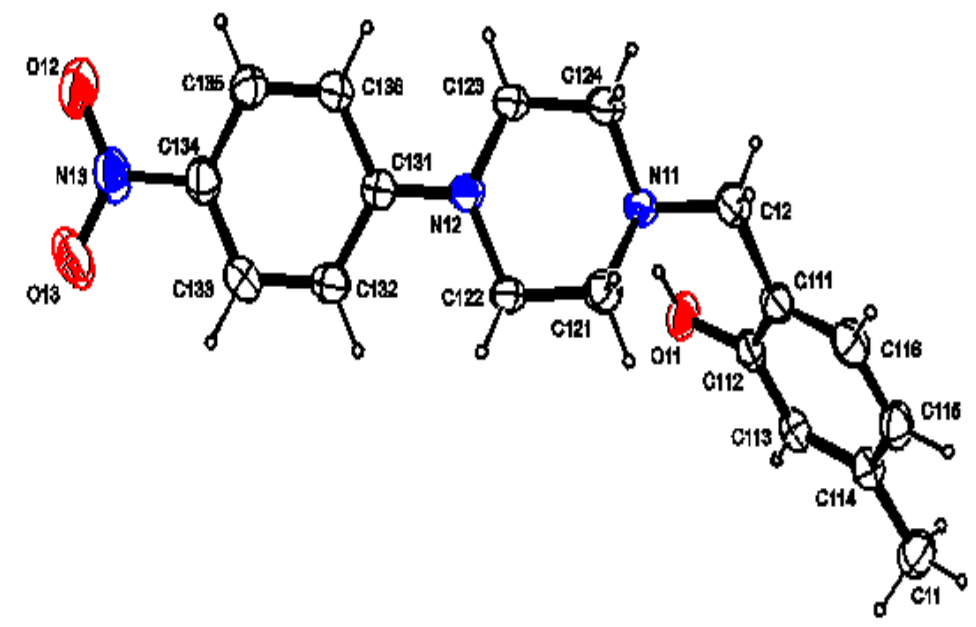

Figure 2. A perspective view of the molecular structure of II with the atom labelling scheme. Thermal ellipsoids are drawn at the $50 \%$ probability level.

\section{Spectral description}

UV spectra of the two Mannich bases are shown in Figure 5. Compound I displayed $\pi-\pi^{*}$ and $\mathrm{n}-\pi^{*}$ transitions at 288 and $305 \mathrm{~nm}$ respectively [12] while compound II showed a intraligand transition attributed to the nitro group at $430 \mathrm{~nm}$ in addition to $\pi-\pi^{*}$ and $\mathrm{n}-\pi^{*}$ transitions at 277 and $369 \mathrm{~nm}$ respectively $[13,14]$.

The FT-IR spectra of the compounds showed vibrations for hydrogen bonded $\mathrm{OH}$ protons around $3300 \mathrm{~cm}^{-1}$ as broad bands while two strong bands for each compound were observed for the $v(\mathrm{C}-\mathrm{N}-\mathrm{C})$ vibrations of the piperazine units in the Mannich bases at about 1320 and 1250 $\mathrm{cm}^{-1}[15]$.

The ${ }^{1} \mathrm{H}$ and ${ }^{13} \mathrm{C}$ NMR spectra of the compounds were recorded $\mathrm{CDCl}_{3}$. In the ${ }^{1} \mathrm{H} \mathrm{NMR}$ spectra, the broad signal at about $10.5 \mathrm{ppm}$ is attributed to the proton of the $-\mathrm{OH}$ groups in each case of the Mannich base. Formation of mono-Mannich bases is proven by singlet signals (of the methylene group that acted as a linker between the phenol and the secondary amine) at about $3.72 \mathrm{ppm}$ and their integration for two protons in each case [16, 17]. The unsymmetrical nature of the piperazine units in the Mannich bases is supported by the observation of two signals of its protons in the range $2.68-3.60 \mathrm{ppm}$. The aromatic protons were observed as multiplets in the range $6.63-8.08 \mathrm{ppm}$ while the aromatic carbons resonated in the range 107-160 ppm. The aromatic carbon carrying the hydroxyl group resonate around $153 \mathrm{ppm}$.

Supporting information

CCDC-1542043 for I, and 11542044 for II contain the supplementary crystallographic data for this paper. These data can be obtained free of charge at http://www.ccdc.cam.ac.uk/const/retrieving.html or from the Cambridge Crystallographic Data Centre (CCDC), 12 Union Road, Cambridge CB2 1EZ, UK; fax: +44(0)1223-336033 or e-mail: deposit@ccdc.cam.ac.uk. 


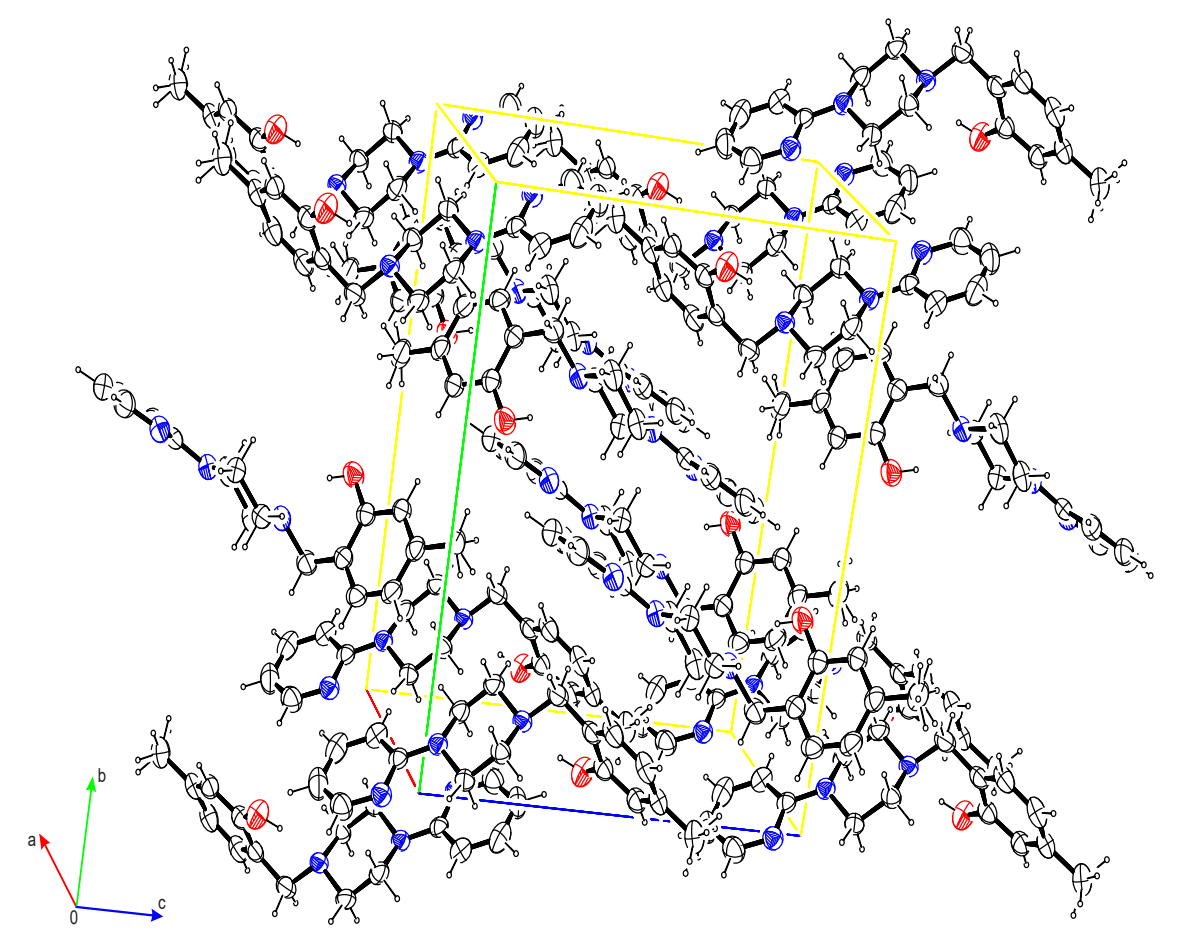

Figure 3. Packing of structure I with only the major disorder components showing. Ellipsoids drawn at $50 \%$ probability level. 


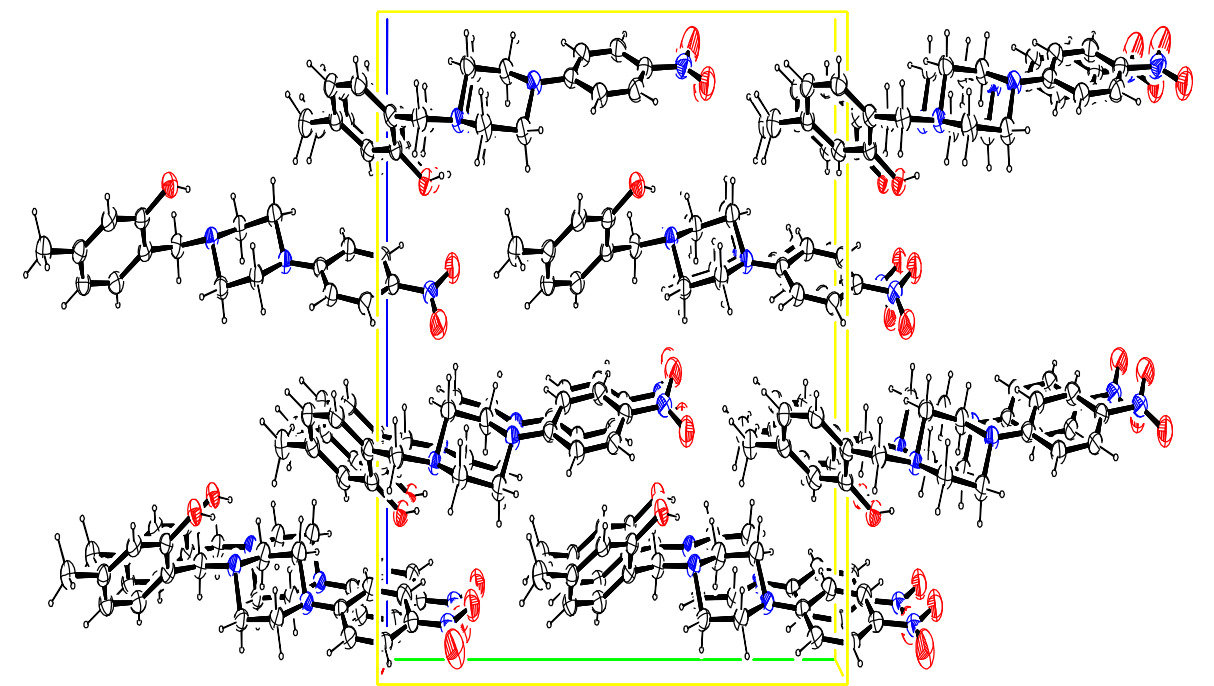

Figure 4. Molecular packing diagram of II viewed normal to (100). Ellipsoids drawn at $50 \%$ probability level.

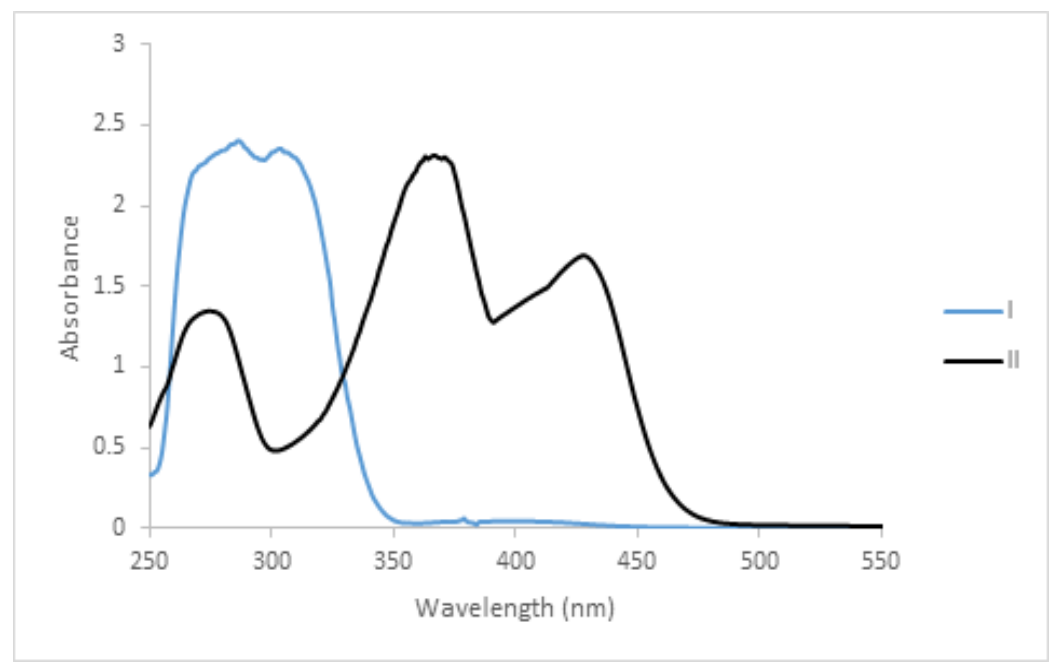

Figure 5. UV spectra of DMF solutions of the compounds I and II.

\section{CONCLUSION}

Two phenolic Mannich bases, 5-methyl-2-((4-(pyridin-2-yl)piperazin-1-yl)methyl)phenol and 5methyl-2-((4-(4-nitrophenyl)piperazin-1-yl)methyl)phenol, were prepared and characterized by spectroscopic techniques. The crystal structures of the compounds are described in details. Both compounds have their structures stabilized by hydrogen bonds and $\pi \cdots \pi$ interactions. 


\section{ACKNOWLEDGMENTS}

One of the authors (Ayowole Ayeni) thanks the Tertiary Education Trust Fund, Nigeria (TET

Fund) for providing Scholarship and Rhodes University, South Africa for Research space.

\section{REFERENCES}

1. Dimmock, J.R.; Kumar, P. Anticancer and cytotoxic properties of Mannich bases. Curr. Med. Chem. 1997, 4, 1-22.

2. Roman, G. Mannich bases in medicinal chemistry and drug design. Eur. J. Med. Chem. 2015, 89, 743- 816.

3. Ayeni, A.O.; Watkins, G.M. Biomimetics of mononuclear and dinuclear $\mathrm{Cu}$ (II) and $\mathrm{Fe}(\mathrm{III})$ complexes of a newly synthesised piperazyl Mannich base with or without thiocyanate towards catechol. Monatshefte für Chemie - Chemical Monthly, 2018, 149, 2175-2182.

4. Ayeni, A.O.; Watkins, G.M. Kinetic studies of the impact of thiocyanate moiety on the catalytic properties of $\mathrm{Cu}(\mathrm{II})$ and $\mathrm{Fe}(\mathrm{III})$ complexes of a new Mannich base. J. Mol. Struct. 2018, 1158, 19-25.

5. APEX2, SADABS and SAINT, Bruker AXS Inc.: Madison, Wisconsin, USA; 2010.

6. G.M. Sheldrick, Crystal structure refinement with SHELXL. Acta Crystallogr. 2015, A71, 3-8.

7. G.M. Sheldrick, Crystal structure refinement with SHELXL. Acta Crystallogr. 2015, C71, 38.

8. C.B. Hübschle, G.M. Sheldrick, B. Dittrich. ShelXle: A Qt graphical user interface for SHELXL. J. Appl. Cryst. 2011, 44, 1281-1284.

9. Latif, T.; Javed, T.; Lynch, D.E.; Pryce, R.J.; Byriel, K.A. X-Ray crystal structure of N-[3diethylaminomethyl)-4-hydroxyphenyl]acetamido and its hydrochloride salt. Two forms of an important precursor in the synthesis of anti-tuberculosis drugs. Aust. J. Chem. 1999, 52, 909-913.

10. Filarowski, A.; Szemik-Hojniak, A.; Glowiak, T.; Koll, A. Anomalous strengthening of the intramolecular hydrogen bond by steric repulsion. J. Mol. Struct. 1997, 404, 67-74.

11. Ayeni, A.O.; Watkins, G.M.; Hosten, E.C. Polymorphism of a new Mannich base - [4methyl-2-((4-(4-nitrophenyl)piperazin-1-yl)methyl)phenol]. J. Mol. Struct. 2018, 1160, 3845.

12. Zhu, M.T.; Qiu, X.Y.; Liu, S.J.; He, L.Y.; Xu, D.Z.; You, Z. Synthesis, characterisation and crystal structures of hydrazone compounds derived from isonicotinohydrazide. Bull. Chem. Soc. Ethiop. 2018, 32, 125-132.

13. Liu, B.; Lin, X.; Li, H.; Li, K.; Huang, H.; Bai, L.; Hu, H.; Liu, Y.; Kang, Y.Z. Luminescent coordination polymers for highly sensitive detection of nitrobenzene. Cryst. Growth Des. 2015, 15, 4355-4362.

14. Kumar, S. Spectroscopy of Organic Compounds in Organic Chemistry, National Science Digital Library at NISCAIR: India, e-books; 2006; pp 14-17.

15. Cretu, C.; Tudose, R.; Cseh, L.; Linert, W.; Halevas, E.; Hatzidimitriou, A.; Costisor, O.; Salifoglou, A. Schiff base coordination flexibility toward binary cobalt and ternary zinc complex assemblies. The case of the hexadentate ligand N,N,O-bis[(2hydroxybenzilideneamino)-propyl]-piperazine. Polyhedron 2015, 85, 48-59.

16. Brycki, B.; Maciejewska, H.; Brzezinski, B. Preparation and NMR characterisation of hydrogen bonding in 2- and 2,6-bis-(N,N-diethylaminomethyl)-4R-phenols. J. Mol. Struct. 1991, 246, 61-71.

17. Farooq, A.; Imran, M.; Iqbal, Z.; Bokhari, T.H.; Latif, S.; Farooq, A.; Liaqat M.; Mitu, L. Synthesis, Structural and photo-physical studies of transition metal complexes with Mannich base derived from 2-mercaptobenzimidazole. Bull. Chem. Soc. Ethiop. 2018, 32, 481-490. 